BORBÉLY-PECZE, Tibor Bors ${ }^{1}-$ HUTCHINSON, Jo ${ }^{2}$

\title{
WORK-BASED LEARNING AND LIFELONG GUIDANCE POLICIES ACROSS EUROPE
}

This paper as a shorterned and republished ${ }^{3}$ work of the European Lifelong Guidance Policy Network Concept Note on work-based learning and lifelong guidance policies discusses the relationship between lifelong guidance and work-based learning. While these are distinct activities, they are often advanced as approaches to answering similar broad policy challenges, such as developing a skilled and socially inclusive population, ensuring engagement with education and work, and helping people to progress and live happy and useful lives. This paper argues that lifelong guidance can be particularly useful in relation to work-based learning in three main ways:

- Engagement. Increasing citizens' understanding of work-based learning, the routes into it and the rewards of participation.

- Achievement. Helping participants (learners, employers and learning providers) in work-based learning to remain engaged and consider how best to enhance their skills and employability.

- Transition. Assisting the effective utilisation of the skills developed within workbased learning by supporting individuals in transitions from work-based learning programmes to sustainable employment.

The word engagement is used deliberately as it describes the personal preference and associated choices that the french term l'orientation invokes but it also implies two other elements. Firstly it focusses on the perspectives of individual learners (young people and adults) and secondly it implies a more active and deeper level of knowledge and understanding. The word engagement therefore refers the comitment of the individuals for different learning pathways. A strong personal engagement of the learner for a learning option can be also understood as the first preventive step against drop-out and early-school leaving.

Work-based learning performs different functions in relation to European countries' skills systems. For young people, work-based learning provides them with a knowledge and understanding of what work is, and what occupational areas they are attracted to. Later on, it provides training for young people to build specific competences needed for particular jobs. Work-based learning also provides a form of active labour market intervention to motivate skill and reward young people who are having difficulties in making the move from

\footnotetext{
${ }^{1}$ https://www.linkedin.com/in/borb\%C3\%A9ly-pecze-bors-24a7003b

2 http://www.derby.ac.uk/staff/jo-hutchinson/

${ }_{3}^{3}$ The original report was produced for the European Lifelong Guidance Policy Network (ELGPN) supported by the European Commission as a Concept Paper in 2014. The full paper is availabel in English and Portugese under the following link: http://www.elgpn.eu/publications/elgpn-concept-note-no.-5-work-based-learningand-lifelong-guidance-policies The authors are thankfull for the Network and the University of Jyvaskyla for the republishing rights.
} 
education to employment. In addition, it offers workers whose skills lose their value in the labour market with a way to retrain and re-integrate to the modern economy.

Work-based learning has strong associations with vocational education and training in the form of apprenticeships and traineeships. However, it is worth stating that in this paper we perceive work-based learning to necessarily incorporate significant periods of time within the workplace and to include episodic periods of learning as people progress through their careers. Therefore, in this article we are focusing on linking lifelong guidance with all types of work-based learning forms, at any age and any stage of the lifespan.

Work-based learning therefore plays a dual function alongside the lifelong guidance process. It offers young people a way of learning about jobs and work to help inform their choices; but it also provides skills, knowledge and accreditation which give people access to opportunities. Making and implementing decisions throughout life requires strong understanding of the labour market structure, the nature of different vocational pathways, the content of the different occupations and occupational outlooks (labour market intelligence), but is also deeply cross-linked with self-awareness and the ways individuals identify themselves in learning and working. Matching between individuals and job positions is usually sustainable only if these decisions are based on personal understanding of the self, the labour market and occupational needs. Different forms of work-based learning can provide opportunities for Europeans to learn for jobs from jobs.

The same "dual" viewpoint is valid for other sectors as well: for example, in higher education where college-based training is often combined with workplace-based experiences; or in the utilisation of active labour market policy tools such as labour market training or wagesubsidies. In some regions of Europe continuing professional development (CPD) as a term also has been used since the 1980 s to describe the lifelong process of (continuing) vocational training.

For some countries and some industrial sectors work-based learning is part of their cultural heritage, as well as providing the basis for sustained economic growth through the continuing supply of skilled young people into businesses. Practices such as mentoring and co-referral between education providers and employers are an established part of the industrial practices that underpin growth and innovation.

Work-based learning has a strong impact on individuals' lives and also on the labour market if these activities are based on individual decisions which are aligned both with (i) economic and labour market needs but also with (ii) individual career constructions which keep the individuals moving towards certain educational, economic and labour market targets and translating these objectives to personalised ones. Engagement in any type of work-based learning as well as successful graduation from it depend upon strong correspondence with the individuals' work values, interests, skills and motivations. It is therefore crucial to discuss the role of lifelong guidance within this process.

This paper describes work-based learning (WBL) and its different forms in relation to different part of the individuals' life path. It then connects future challenges of work-based learning developments across Europe with the agenda of lifelong guidance (LLG). The cross- 
connection of these two issues (WBL and LLG) is certainly not a new idea, but during the implementation phases of national school, adult education, VET system or PES reforms, these links are sometimes forgotten or not fully defined and implemented. The paper seeks to build a common understanding of the supporting role of lifelong guidance as a service, as a system and as a policy for a more effective work-based learning models across Europe.

\section{The related purposes of work-based learning and lifelong guidance}

\section{Work-based learning}

The nature of work and the world of work have always been changing. Prevailing ideas of globalisation, specialisation and de-industrialisation are being challenged by academics, politicians and industrialists. The recent financial crises and recessions have generated new ways of thinking: notions of insourcing, relocation of jobs and re-industrialisation (Westkämper, 2014) are increasingly talked about in political debates and the media. However, these new trends are linked with different levels of production and productivity in the Western world than before. This has strong implications for the labour force, where the "one vocation and one job" paradigm is no longer an expectation. This is a significant issue for the European Union and for each of its Member States.

Several European initiatives target this challenge. Linking the world of work with the world of learning through work-based learning is one of these. This mode of learning not only integrates labour market demand and supply, but also opens up social debates on the career adaptability (Savickas, 2008) of the European labour force for our uncertain labour market. Multiple bridge-building between work, learning, individuals and families also means that new types of cognitive competencies such as career management skills for life are necessary.

The European Council (2013) and the Council of the European Union (2013b, 2014) have been promoting the development of a range of work-based learning infrastructures (e.g. on traineeship on alliance for European apprenticeship, and on the Youth Guarantee), not least as a means of generating excellent labour market and social inclusion outcomes. However, they acknowledge that the meanings of these concepts are not the same across the different Member States. Some countries have strong, well-established and culturally embedded systems such as the dual training system in Austria and Germany, or well-advertised and well-known traineeship/internship opportunities as in Ireland, the Netherlands, Portugal and the United Kingdom. Others continue to develop their offer in this area for young people and adults. The European Alliance for Apprenticeships is building actions to promote reform of apprenticehip systems, promote their benefits and use funding and resources smartly (Council of the European Union, 2013c).

The nature, duration and investment in work-based learning is based on a number of variables. These include the role of social partners, th engagement of companies in tripartite dialogue, average size of the firms (e.g. mainly micro and small or medium and large), degree of foreign direct investment, shape of the banking system, availability of loans, cultural 
heritage of a region, familial expectations, development of technology in a region, and intrinsic regional geographical opportunities.

As the nature of work changes, the nature of work-based learning may also need to change. If multiple transitions between careers becomes common over the working life, alongside the incidence of portfolio working, project-based jobs, virtual offices and other aspects of work change, then we might need to reconceptualise work-based learning structures as a series of short-term interventions in any working life rather than a longer-term period of training relating to multiple aspects of a single job role.

Skills systems that equip people with a single set of skills or functional knowledge at the outset of their working life are inadequate within this context. People who are active in the labour market have constantly to acquire new skills within their existing work, to achieve promotion, to develop a deeper skill-set in an occupation, or to move into and between places of work. Portability of work-base-learnt skills or learning outcomes is still not fully developed in Europe; however, the evaluation of these personal skills is a formal or informal part of European companies' recruitment processes (Cedefop, 2014a). The skills that are needed as work changes are often developed at the workplace or as a blended approach combining learning at work with learning in education or training. This type of work-based learning has several forms, providing opportunities to:

- gain personalised experiences from the world of work and the nature of different professions and jobs before the vocational education/training begins (orientation);

- develop a better understanding of the chosen occupational track based on real work experiences during the training period / vocational education years;

- support easier access of individuals to the labour market at any age of their life through evidencing their achievements by accreditation;

- support transitions through to employment by providing concrete experiences;

- give people who have become unemployed, or who are having difficulty making their first transition into the labour market, the motivation, experience and skills to effect a more rapid transfer to employment (active labour market policies).

Work-based learning therefore offers ways to orient people towards particular occupations before they make career choices. It gives them an opportunity to gain and practise skills that are relevant to all work (such as communication and commercial skills) and simultaneously relevant to a particular occupation (to support economic growth), and through accreditation and experience it offers a passport to help secure sustainable employment.

Work-based learning clearly has strong associations with vocational education and training, and in many cases the discussion of one can be conducted interchangeably with the other. However, it is worth stating that in this paper we perceive work-based learning to necessarily incorporate significant periods of time within the workplace (rather than an entirely college-based training programme, for example), and to include episodic periods of learning as people progress through their careers. Therefore, in this paper we are focusing 
on linking lifelong guidance with all types of work-based learning forms, at any age and any stage of the lifespan.

\section{Lifelong guidance}

The purpose of lifelong guidance has strong affiliation to the purpose of work-based learning. It has been described by $\operatorname{OECD}(2004$, p.19) as follows:

"Career guidance refers to services intended to assist people, of any age and at any point throughout their lives to make educational, training and occupational choices and to manage their careers. Career guidance helps people to reflect on their ambitions, interests, qualifications and abilities. It helps them to understand the labour market and education systems, and to relate this to what they know about themselves. Comprehensive career guidance tries to teach people to plan and make decisions about work and learning. Career guidance makes information about the labour market and about educational opportunities more accessible by organising it, systematising it, and making it available when and where people need it."

Thus, if the purpose of work-based learning is to orientate, to provide learning opportunities and to equip people with the skills and experience to progress to sustainable employment, then lifelong guidance is the process that helps to ensure that people are aware of this, and have the skills and outlook to maximise the benefits from the experience. Lifelong guidance can be particularly useful in relation to work-based learning in three main ways:

- Engagement. Increasing citizen's understanding of work-based learning, the routes into it and the rewards of participation.

- Achievement. Helping participants in work-based learning to remain engaged and consider how best to enhance their skills and employability.

- Transition. Assisting the effective utilisation of the skills developed within workbased learning by supporting individuals to transition from work-based learning programmes to sustainable employment.

Significant decisions have to be taken in advance of taking up a work-based learning opportunity, and the role of lifelong guidance in engaging people with these opportunities is well-established. But there is a misconception that once people have enrolled on an apprenticeship or commenced a traineeship/internship, they no longer require lifelong guidance. However, decisions often have to be taken within a programme, and support is needed towards the end of a learning experience to help the transition into an employment contract. This could be with the employer hosting the work-based learning opportunity, but this is not necessarily the only option, nor indeed may it be the best option for an individual. The need for personal, well-informed guidance, based on current and objective labour market information that is available to an individual at the point at which they need it, remains true for work-based learners. 
Work-based learning structures and their associated learning opportunities benefit from effective integration with lifelong career guidance services. OECD (2010) has highlighted the emerging role of lifelong guidance concerning good-quality vocational education and training:

"One way of ensuring that vocational programmes meet labour market needs is to give VET students good guidance. As careers diversify, career choices and therefore career guidance are becoming both more important and more demanding. To meet this challenge, there needs to be a coherent career guidance profession, with personnel experienced in labour market issues and separated from psychological counselling. Guidance needs to be adequately resourced, with some assurance of pro-active one-to-one delivery of guidance at key career decision points. Guidance personnel need to have an independent base to underpin their objectivity, and be able to call on a wide range of information and web-based material. Strong links between schools and local employers are very important means of introducing young students to the world of work. Guidance initiatives also need to be carefully evaluated" (p.77).

\section{Lifelong guidance and work-based learning practices across Europe \\ Introduction}

The policy goals for work-based learning are to move towards a knowledge economy within a socially cohesive society based on sustained economic growth. The goals for lifelong learning are to support individuals to integrate, enrich and develop within such a socioeconomic structure. The two areas are thus mutually reinforcing in policy terms. At a strategic level, lifelong guidance can provide a bridge to arbitrate between the needs of different stakeholders, and a means to achieve broader strategic policy goals.

Lifelong guidance services also have a role to play in supporting the effective operation of work-based learning with dynamic labour markets. This section outlines the role that lifelong guidance plays both strategically and practically for work-based learning and work-based learners.

\section{Strategic links}

Lifelong guidance services have a range of functions which are associated with bridging. Firstly, they support individuals to build career management skills that enable them to bridge their career transitions from education and learning to training and earning:

"Career management skills refer to a whole range of competences which provide structured ways for individuals and groups to gather, analyse, synthesise and organise self, educational and occupational information, as well as the skills to make and implement decisions and transitions" (ELGPN, 2010, p.23). 
Secondly, guidance services can provide a bridge between employers and learning providers, helping to shape and refine training and employment opportunities that align the needs of both groups of stakeholders.

The importance of linking work-based learning including apprenticeships and traineeships/ internships with lifelong guidance lies with meeting the needs of both learners and employers. In some economic systems the partnership between the state and industry is closely aligned and forward-looking: in such situations the planning and resourcing of workbased learning opportunities should be in line with labour market projections. But this may not always be the case, and there is a danger that in systems which incentivise accredited learning over employability, work-based learning opportunities will be overly responsive to learner demand. In these cases the role of lifelong guidance is to act as an arbiter between the world of work and the world of learning, seeking to direct learning opportunities towards labour market opportunities.

Lifelong guidance in a work-based learning context can also help to achieve mobility of the workforce between EU Member States and to promote social mobility. Lifelong guidance services can challenge stereotypical thinking and broaden the aspirations of disadvantaged groups. In so doing they can help people to access opportunities that might otherwise have been denied to them. The existence and quality of labour market information/intelligence (LMI) play a crucial role in this process. In some countries LMI is not closely connected with personal preferences (like work values or work interests); unless this self-knowledge is linked to the labour market and training realities, there is little chance for well-established personal decision-making. Lifelong guidance as a system and as a service can integrate LMI with personal self-learning processes, and accordingly should provide better outcomes at both individual and system level than LMI alone.

Lifelong guidance services alongside the range of social partners can also play a role in assuring quality interventions that build genuine and sustainable impacts. The Quality Framework for Traineeships (Council of the European Union, 2014) will support the improvement of working conditions and the learning content of traineeships. Social partners including lifelong guidance services can play a role in providing trainees with targeted information of opportunities, rights and responsibilities as well as by building a resource for simple and concise model traineeship agreements.

Thus lifelong guidance services have a key role to play in shaping skills systems and helping labour markets to operate more effectively, helping European citizens to link their own learning and career plans as well as previous working and learning experiences with learning and working opportunities. Lifelong guidance services also support individuals through their careers in a number of fundamental ways, such as providing labour market information as well as information about learning opportunites (e.g. CPD, C-VET) and supporting individuals to link this objective information with their subjective career views and values.

\section{Practice links}

The different elements of lifelong guidance are presented before, during and after workbased learning forms at different levels of intensity. 
Work-based learning is about providing opportunities to learn about work and about jobs, and this is often most effective within the secondary education phase. There are clear associations between activities such as work experience and employer engagement in schools and those that are undertaken within a broader career education curriculum such as learning about jobs, about different progression routes and about ensuring that aspirations are both broad and high. Career information, including labour market information, is crucial to support individual decision-making processes before enrolment. In Figure 1 below, the relationship between practical activities that help young people in particular to learn about jobs and work and those that are associated with the engagement purpose of guidance is clear.

Similarly, the links between learning how to do a job and the guidance focus on achievement on course are evident. Work-based learning in this respect is about teaching a person about the functions associated with a particular job and acquiring the skills to undertake it. Guidance can be a mutually reinforcing activing that supports study and retention skills as well as individual mentoring and counselling. Career counselling is a tool to support the development of individuals' learning and working action plans, but also a tool to support initial engagement (with career starters) or re-engagement with work after the training process.

Finally, associations can be made between the capacity of work-based learning to help people to progress into or in work and the same aspirations for lifelong guidance. Both support the development of career management skills that are useful for job-search and career negotations such as conflict in work or salary negotiations. Work-based learning can also be a workforce development tool for employed or self-employed people, while career counselling can support individuals in gaining better understanding of their labour market and business perspectives.

Figure 1: Linking the dual purpose of work-based learning with lifelong guidance

\begin{tabular}{|c|c|c|c|}
\hline Examples of activity & $\begin{array}{l}\text { Work-based } \\
\text { learning }\end{array}$ & $\begin{array}{l}\text { Lifelong } \\
\text { guidance }\end{array}$ & Examples of activity \\
\hline $\begin{array}{l}\text { Work experience } \\
\text { Employer engagement in } \\
\text { education } \\
\text { Taster courses } \\
\text { Summer schools }\end{array}$ & $\begin{array}{l}\text { Learning about } \\
\text { work } \\
\text { Learning about } \\
\text { jobs }\end{array}$ & Engagement & $\begin{array}{l}\text { Decision-making skills } \\
\text { Labour market information } \\
\text { Building ambition } \\
\text { Broadening aspiration }\end{array}$ \\
\hline $\begin{array}{l}\text { Apprenticeships } \\
\text { Traineeships/internships }\end{array}$ & $\begin{array}{l}\text { Learning how to } \\
\text { do a job }\end{array}$ & Achievement & $\begin{array}{l}\text { Coaching and mentoring } \\
\text { Prevention of drop-out } \\
\text { Pastoral and study support }\end{array}$ \\
\hline $\begin{array}{l}\text { Continuing professional } \\
\text { development } \\
\text { Voluntary work } \\
\text { Job rotation }\end{array}$ & $\begin{array}{l}\text { Learning how to } \\
\text { progress in } \\
\text { work }\end{array}$ & Transition & $\begin{array}{l}\text { Opportunity awareness } \\
\text { Labour market analysis } \\
\text { CV \& interview skills } \\
\text { Resilience }\end{array}$ \\
\hline
\end{tabular}


ELGPN member-countries have provided examples of effective integration of lifelong guidance with respect to work-based learning. These encompass the three elements outlined above:

- Engagement before entering programmes and typically whilst still at secondary school.

- Achievement whilst experiencing work-based learning, to encourage participation and retention as well as successful completion.

- Transition after leaving vocational programmes, to include personalised follow-up and on-going career support to help individuals develop their own career management skills as well.

\section{Engagement practices}

Guidance services perform their strategic role with respect to the design of work-based learning as they do for other aspects of the labour market. In most cases there are no special lifelong guidance services that support only work-based learners, but European citizens can use general guidance services, whether run by educational providers (e.g. Poland), by vocational schools (e.g. Netherlands) or by the Public Employment Service (e.g. Czech Republic, Germany, Hungary).

In many cases these guidance services will support people into work-based learning opportunities through a combination of information, education and counselling. For example, in Northern Ireland, careers advisers explore training as an option with young people at key transition points. Prior to entering training provision, each young person, if required, will receive a pre-entry guidance interview from a careers adviser.

In some countries the guidance offer is structurally embedded within a programme of workbased learning. For example, in Luxembourg, some programmes require participants to enrol with the PES prior to entering a work-based learning opportunity. The PES provides counselling and recruitment services to ensure that there is a mutually beneficial match between the employer and the work-based learner.

\section{Achievement}

In some cases this embedded approach operates throughout the lifetime of the learning programme. Some national lifelong guidance systems try to cover the three functions under one roof, providing before, on-programme and follow-up services through the same state agency (e.g. NAV in Norway) or in guidance centres of the local/regional authorities (e.g. Denmark). In addition, where work-based learning is part of a package of active labour market measures to encourage employability, lifelong guidance services remain available to people who have experienced some form of work-based learning and require additional support to enable them to secure employment.

An alternative approach to this model is for teachers and trainers to provide guidance within an embedded model. On-programme guidance services can be provided by school staff or specialised guidance professionals/teachers employed within schools and training providers. In Austria and Denmark, specially-trained professionals help the students; the same situation 
applies in Ireland for colleges. In Germany, the federal employment agency (BA) supports the VET schools, whilst academics within the higher education institutes are responsible for guidance. In Hungary, the youth vocational training schools have a special subject on guidance as part of the curriculum.

\section{Transition}

On leaving a work-based learning opportunity, few countries have specialist support for individuals outside an ALMP programme; rather, the individuals then access the general guidance service if help is required.

Work-based learning has considerable potential to support effective integration of the world of work with the world of learning, but this is clearly complex and there is a need for brokerage between these two worlds. Flexibility of the labour force for the fast-changing economic and labour market needs can be only guaranteed if, as a part of the high quality of vocational and academic programmes, students learn how to deal with career adaptability. For this purpose, lifelong guidance is a strategic partner both prior to entering a work-based learning programme and within the programme. Within programmes, Watts (2009) states that two further principles are important: namely, that career guidance should be available at all relevant decision points including on exit; and that career education programmes have an important role to play both in preparing participants for future career decisions and in supporting the transferability of their learning.

\section{Dual practice within active labour market measures}

It is common practice for countries to integrate an element of work-based learning into programmes that seek to redress labour market imperfections. The work-based component can support a range of different groups within the labour market, including young people who might otherwise disengage from learning, new entrants to the labour market who need work experience to secure employment, and unemployed people who need to remain connected with the labour market or to secure new skills. Examples include:

- In the Netherlands, the School Ex Programme is designed to give young people who might otherwise drop out of learning an opportunity to receive counselling and/or work experience. The experience of work is used to motivate their ambitions and to guide them in their transitions either to further learning or to the labour market.

- In Latvia, work-based learning is used to give new entrants to the labour market the opportunity to gain some general work experience and to facilitate long-term inclusion into the labour market.

- In other EU Member States, periods of work-based learning are designed for people who are unemployed, either to provide them with new skills for new jobs or to help to keep them engaged and prevent long-term unemployment. For example, in Poland, work practice is offered for 6 months (or 12 months for a person aged up to 30 years old) to unemployed people within the workplace. Examples of similar programmes are found in Greece where programmes are available to people at all 
skill levels, in Malta where work exposure schemes are targeted at sectors where there is a shortfall of specialised workers, in Ireland where there is a National Internship Scheme and in Portugal, Employment-Insertion Contracts are used to develop social and professional skills of unemployed by linking them with socially useful work

In all these examples of ALMPs, the integration of employers within the schemes - and the search for market-based solutions - is an important component. From the employers' perspective, work-based learning offers a number of advantages: it allows them to shape the training that is offered within public provision; it gives them the opportunity to search for talent; and it helps to ensure that all entrants to the labour market are better prepared and "skills ready". However, receiving trainees also creates costs for enterprises in terms of time, tools and raw materials, for example. In some national systems, these costs are absorbed by all employers either directly or through taxation. In others, employer incentives have to be deployed, such as the offer of tax relief, brokerage services or direct inducements. This is more often the case where the trainee needs additional support to become work-ready and where their learning needs include learning about work and learning about jobs. In many of the examples above, the costs of employment are subsidised by the state. For example, in Poland, people on the work practice programme are entitled to a monthly scholarship equal to $120 \%$ of unemployment benefit. In Latvia, the state will subsidise employment and training costs, but there is an expectation that once training is finished the employer will hire the participant in an appropriate occupation for at least 6 months.

Specialist employment guidance services are needed that offer expertise in the various modes of work-based learning to support young people and adults into these opportunities, through them, and to ensure that people are supported in their transition from work-based learning where it is needed. These professional services will be focused on university graduates as well as on young people with lower-level skills, and thus will need to be accessible to a broad spectrum of the labour market.

\section{Conclusions}

Different countries in Europe have different education and training structures. Within those structures, work-based learning takes many different forms. Fundamentally, though, workbased learning can be described from the perspective of the individual as bringing the different natures of work closer to European youth, adults and their families, to make different occupations, sectors and job roles more familiar, and to develop in them the motivations, skills and aspirations to succeed in work. Throughout life, such experiences help to develop career decision-making skills and career adaptability.

From the labour market demand side, work-based-learning forms help employers from allsized organisations across different sectors to develop their own recruitment and human resource practices, and learn from and inform curricula being followed in schools and colleges, all of which serve the employers' long-term goals. 
Utilisation of job-related skills is connected with the individual's personality which includes, for example, work interests, motivations and values. Lifelong guidance is essential to provide meaning for any types of work-based learning at the personal level and to keep the individuals "on the right track" before, during and after the vocational education and training. In this personalised context "right track" has an individualised meaning based on individual interests, values and skills.

Work-based learning processes help people to learn about work, about particular jobs, about the skills needed to perform specific jobs, and about how to move between jobs. The most commonly referenced form of work-based learning is apprenticeship. ELGPN membercountries share a broadly common understanding of the structure and purpose of apprenticeships. This is not the case when referring to traineeships and internships, where different definitions apply between these two terms across countries. From these descriptors of the features of apprenticeships and traineeships/internships, it is clear that as a concept work-based learning is: (a) part of active labour market measures; (b) part of mainstream VET (for youth and adults) at all skill levels; and (c) part of a process of lifelong learning.

Just as work-based learning extends over the life course, so does career guidance. Lifelong guidance operates at strategic levels to help structures develop in ways that enhance the operation of the labour market and achieve broader policy goals such as labour market and social mobility.

In the context of work-based learning, lifelong guidance supports individuals into, through and beyond individual episodes of work-based learning. Such guidance can operate parallel to work-based learning, being part of a suite of activities that are available from specialist services and PES to individuals whatever their learning context. A different model is for a guidance element to be integrated within the work-based learning programme and delivered either by specialist services and PES or by trained teachers and tutors. A third model is for guidance services to manage or co-ordinate a range of work-based learning opportunities as part of active labour market measures which are designed to improve employability.

Work-based learning can be an effective way to bring the world of work closer to citizens of any age. It helps the familiarisation process with workplaces, and how literacy, numeracy and ICT skills are applied within the workplace, alongside the social contract of work and other implicit learning that comes from experience within a workplace. Lifelong guidance fosters individualisation of the work-based learning process, often as part of the lifelong learning process.

These advantages accrue from different work-based learning forms and for different groups of citizens, in different life circumstances and at different ages. However, such advantages are not automatic, nor are they necessarily well understood by indivdiduals, the business sector or schools. Therefore it is important to make these learning options transparent and permeable both for the participants and also for the business sector and schools.

Workplace practice is part of individuals' professional socialisation process: therefore the quality of the job and of the apprenticeship or traineeship/internship matters. It is especially 
important for career starters and young professionals, as professional socialisation has started in the VET school and during the workplace practices, but the first two to three years in the labour market construct their understanding of work which they will broadly then carry for four to five decades, until retirement age (Borbély-Pecze, 2012). This indicates that work-based learning is not only a work position (often for limited wages) but also a preparatory place for socialisation in work and personal professional development in a certain occupation or occupations.

Vocational education and training / active labour market training programmes at any age can be more effective with built-in lifelong guidance services. These services can help the citizens and families to clarify their training/learning paths but also support employers to identify certain needs for certain job posts before entry. Lifelong guidance services as part of the programmes support preventing drop-out and early school-leaving through customising learning to individuals' need. Last but not least, lifelong guidance plays an important role on exit, supporting learners in (re)entering the labour market and also in entering particular workplaces through the mobilisation of their own career management skills.

\section{References}

- Borbély-Pecze, T.B. (2012). Átalakuló ifjúsági pályautak Munkaügyi Szemle (Changing youth career tracks). Hungarian Labour Market Review, IV: 79-84.

- Borbély-Pecze, T.B. \& Hutchinson, J. (2013). The Youth Guarantee and Lifelong Guidance. Jyvaskyla, Finland: European Lifelong Guidance Policy Network.

- Cedefop (2002). Towards a history of vocational education and training (VET) in Europe in a comparative perspective. In Proceedings of the First International Conference, Florence, Volume I: The Rise of National VET Systems in a Comparative Perspective. Luxembourg: Publications Office of the European Union.

- Cedefop (2004). From divergence to convergence: A history of vocational education and training in Europe. European Journal of Vocational Training, 34: 6-17.

- Cedefop (2011). Learning while Working: Success Stories on Workplace Learning in Europe. Luxembourg: Publications Office of the European Union.

- Cedefop (2014a). Use of Validation by Enterprises for Human Resource and Career Development Purposes. Cedefop Reference Series No.96. Luxembourg: Publications Office of the European Union.

- Cedefop (2014b). Navigating Difficult Waters: Learning for Career and Labour Market Transitions. Research Paper No. 42. Luxembourg: Publications Office of the European Union.

- Council of the European Union (2004). Draft Resolution of the Council and of the Representatives of the Member States Meeting within the Council on Strengthening Policies, Systems and Practices in the Field of Guidance throughout Life in Europe. Brussels, 18 May.

- Council of the European Union (2008). Council Resolution on Better Integrating Lifelong Guidance into Lifelong Learning Strategies. Brussels: CEC. 
http://www.consilium.europa.eu/ueDocs/cms Data/docs/pressData/en/educ/10423 $\underline{\text { 6.pdf }}$

- Council of the European Union (2009). Council Conclusions of 12 May 2009 on a Strategic Framework for European Cooperation in Education and Training (ET 2020). 2009/C 119/02.

- Council of the European Union (2013a). Employment and Social Developments in Europe 2012 SWD (2013) 2 final VIII/IX, Brussels, 22 January.

- Council of the European Union (2013b). Recommendation of 22 April 2013 on Establishing a Youth Guarantee. Brussels: CEC.

- Council of the European Union (2013c). European alliance for apprenticeships. Council Declaration Brussels: CEC.

- Council of the European Union (2014). Council Recommendation on a Quality Framework for Traineeships. Brussels: CEC.

- Council of the European Commission: Employment Committee (EMCO) (2010). Making Transitions Pay.

- European Commission (2010). Communiqué of the European Ministers for Vocational Education and Training, the European Social Partners and the European Commission: The Bruges Communiqué on Enhanced European Cooperation in Vocational Education and Training for the Period 2011-2020. Bruges, 7 December.

- European Commission (2012a). Apprenticeship Supply in the Member States of the European Union. Brussels.

- European Commission (2012b). Employment and Social Developments in Europe. Brussels: DG EMPL.

- European Commission (2013a). Communication from the Commission to the European Parliament and the Council on Strengthening the Social Dimension of the Economic and Monetary Union. MEMO/13/837 02/10/2013 Brussels.

- European Commission (2013b). Apprenticeship and Traineeship Schemes in EU27: Key Success Factors. A Guidebook for Policy Planners and Practitioners. Luxembourg.

- European Commission (2014). Economic Forecast, Winter 2014. Directorate-General for Economic and Financial Affairs.

- European Council (2013). Declaration: European Alliance for Apprenticeships. Luxembourg.

- European Lifelong Guidance Policy Network (2010). Lifelong Guidance Policies: Work in Progress. A report on the work of the European Lifelong Guidance Policy Network 2008-10. Jyvaskyla, Finland: ELGPN.

- European Trade Union Confederation (2013) Towards a European quality framework for apprenticeships and work-based learning. Best practice and trade union contributions. London: Unionlearn and Brussells: ETUC.

- European Training Foundation (2014) (R. Sweet). A Handbook for Policy Makers and Social Partners in the ETF Partner Countries. Turin: ETF.

- Eurostat (2014). Unemployment Statistics. Last accessed 15 September.

- ILO (2014). Global Employment Trends 2014: Risk of Jobless Recovery? Geneva: ILO.

- Organisation for Economic Co-operation and Development (2004). Career Guidance and Public Policy: Bridging the Gap. Paris: OECD. 
- Organisation for Economic Co-operation and Development (2010). Learning for Jobs. Paris: OECD.

- Savickas, M.L. (2008). Helping people choosing jobs: A history of the guidance profession. In Athanasou, J. \& Van Esbroeck, R. (eds.), International Handbook of Career Guidance, 97-115. New York: Springer.

- UNESCO (2013) (A.G. Watts). Career guidance and orientation. In UNESCO-UNEVOC: Revisiting Global Trends in TVET, 241-273. Paris: UNESCO.

- Watts, A.G. (2009). Learning for Jobs: The Relationship of Career Guidance to VET. Paris: OECD.

- Westkämper, E. (2014). Toward the Re-industrialization of Europe: A Concept for Manufacturing for 2030. New York: Springer.

\section{Abbreviations}

- ALMP Active Labour Market Policy

- EURES European Employment Services

- EMCO Employment Committee

- ETUC European Trade Union Confederation

- FDI Foreign Direct Investment

- LLG Lifelong Guidance

- LMI Labour Market Intelligence

- PES Public Employment Service

- STW School to Work Transition

- VET Vocational Education and Training

- I-VET Initial Vocational Education and Training

- C-VET Continuing Vocational Education and Training (also known as Further Education)

- CPD Continuing Professional Development

- WBL Work-Based Learning. 